\title{
The Relationship Between Feeding Patch Quality and Fodder Species of Wild Elephants in the Teknaf Wildlife Sanctuary, Cox's Bazar, Bangladesh
}

\author{
Amir Hossen ${ }^{1} \&$ Eivin Røskaft ${ }^{2}$ \\ ${ }^{1}$ Department of Zoology, Jagannath University, Dhaka 1100, Bangladesh \\ ${ }^{2}$ Department of Biology, Norwegian University of Science and Technology, NTNU, Realfagbygget 7491 Trondheim, \\ Norway
}

Correspondence: Eivin Røskaft, Department of Biology, Norwegian University of Science and Technology, NTNU, Realfagbygget 7491 Trondheim, Norway

Received: July 30, 2021

Accepted: September 15, 2021

Online Published: November 18, 2021

doi:10.5539/ijb.v13n2p1

URL: https://doi.org/10.5539/ijb.v13n2p1

\begin{abstract}
We examined the relationship between the presence or absence of elephants in patches of land and the most common ecological factors, such as fodder species, water bodies, resting places, elephant movement trails, and soil types, across ten transect sites in the Teknaf Wildlife Sanctuary (TWS), Bangladesh. By ground-truthing 360 line transects and 1080 quadrate blocks, we recorded a total of 184 fodder species, including 71 monocotyledons, 58 dicotyledons, and 55 domesticated plant species. Three categories of domesticated fodder species were recorded that consisted of 13 cultivated crops, 24 vegetables, and 18 homestead garden plants. We also applied dung-pile dissection techniques to a total of 250 dung piles between August 2018 and July 2019. Highly statistically significant differences among the abundances of different fodder species and presence of elephants were found across different transect sites. The average fodder species density was found to be 3.44 plant species per site per $\mathrm{km}^{2}$, while the elephant density was 0.63 individuals per site per $\mathrm{km}^{2}$. A significant strong correlation was found between fodder species density and the number of elephants among the transect sites $(\mathrm{P}=0.02)$. The numbers of ground-recorded fodder species were higher than those found in dung piles. The presence of elephants across transect sites was influenced not only by fodder species but also by other ecological factors, such as water bodies, resting places, movement trails, and soil types.
\end{abstract}

Keywords: Asian elephants, ecological factors, fodder species, dicotyledons, monocotyledons, homestead garden, movement trails, resting places, soil types, water bodies, socioeconomic factors

\section{Introduction}

The presence of elephants in an area depends on its characteristics. Some ecological factors, such as the availability of fodder species, perennial water sources, access to free feeding trails, and undisturbed resting places, are prime requirements for high-quality sites (Desi, 1991; Hedges, Tyson, Sitompul, Gunaryadi, \& Aslan, 2005). Different forms of human activities are considered to present major threats to elephant habitats (Sukumar, 1989a; Mallegowda, Rengaian, Krishnan, \& Niphadkar, 2015). High-quality fodder species are additional prerequisites for the presence of elephants at a site. However, the availability of different fodder species, density, and evenness, which are regulated by soil nutrients, $\mathrm{pH}$ balance, and soil texture along with topographical features and meteorological parameters (e.g., temperature, rainfall, and moisture), are the main characteristics of a habitat (Sukumar, 1990; Vacaylenberg, 1977; Guy, 1975; Jachman, 1983; and Douglas \& Sheldrick, 1964).

Over the generations, there has been a harmonious relationship between mega-herbivores such as elephants and high-quality fodder species in elephant habitats (Baskaran, 1998; Laws, Parker, \& Johnstone, 1975; Jachman, 1983). However, extreme anthropogenic pressures, the effects of climate change, a lack of awareness, corruption, and poor forest management systems have appeared to be leading causes of imbalances in this kind of relationship (Sarker \& Røskaft, 2014; Ishwaran, 1983). Disturbance-free interactions among the diversified biotic and abiotic factors in a habitat can ensure healthy ecological conditions that provide good relationships between fodder and their feeders (Sukumar, 2006). Heterogeneous features are better than homogeneity within in a habitat regarding the potential for high species richness and availability of fodder species within a limited confined landscape (Desi, 1991; Guy, 1975). Furthermore, naturally modified areas of habitats sometimes contain the highest number of fodder species rather than unmodified habitats (Pringle, 2008). However, several driving factors might influence the abundance of fodder species, which can influence the level of high forage quality for elephants (Duncan, 1983). Nutrient flows in habitats promote elephant forage quality 
by regulating the palatability, digestibility, regrowth tolerance, and regenerative capability, as well as low concentrations of toxic components, in elephant fodder species (Augustine \& McNaughton, 1998).

The occurrence of different foraging herbivores, including ruminant and nonruminant herbivores, meso (middle size), and smaller herbivores, varies according to their feeding strategies, food preferences, and choices (Guy, 1975). Most meso and smaller herbivores are selective feeders (Owen-Smith, 2012) and respond to daily demand, body mass, and fodder species availability. However, many mega-herbivores, such as wild elephants, do not follow similar patterns due to their large body sizes and massive daily demands for food (Fornara \& du Toit, 2007). As an example, the daily intake of Asian elephants (Elephas maximus) is approximately 150 to $300 \mathrm{~kg}$ fodder (Sukumar, 1989b), and that of African elephants (Loxodanta africana) is 300 to $400 \mathrm{~kg}$ (Osborn, 1998). Elephant daily food intake rates depend on the elephant physiological conditions, motivations, seasonal variations, types of anthropogenic pressure, availability of fodder species, and even the diversification of habitats (Sukumar, Bhattacharya, \& Krishnamurthy, 1987; Dhaklas \& Ojhai, 1995). The elephants' rates of food intake differ with age, sex, and group size (Stokke, 1999) in addition to water availability, choice items, and timing for a particular feeding strategy (Owen-Smith, 1988; Stokke \& du Toit, 2000). Elephants choose fodder species with different fixed criteria, such as digestibility, palatability, nutritional values, and the presence of secondary components (e.g., tannin and lignin), and they consider the physical and chemical defences of fodder species (Jackman, 1989; duToit, Bryant, \& Frisby, 1990; Dublin, 1996). Furthermore, the diet preferences and consumption rates of elephants are influenced by the presence of secondary toxic components (Guy, 1976b; Lewis, 1986; Owen-Smith, 1988; Jackman, 1989). Many species that are browsed in savannah forests are characterized by stronger chemical defences than bushy forest species (Bell, 1982). Therefore, most woody vegetation in savannah forests contains varying levels of toxic secondary components (Bryant et al., 1991). The toxicity levels of these trees escalate during the dry season and are milder in winter, while they are less toxic during the monsoon season. Elephants are susceptible to toxicity (Doughlas \& Sheldrick, 1964). Nevertheless, lactating females, juveniles, and subadults might be adversely affected by the toxicity of secondary components (Stokke, 1999). Elephants prefer to utilize a wider range of fodder species compared to meso- and small herbivores due to their low digestibility and very high demand for food (Belovsky, 1997), as well as their high risk of suffering from secondary component toxicity. Nevertheless, elephant diet compositions change with the seasons owing to the variations in rainfall, temperature, day length, and the availability of fodder species. Some fodder species even lose their greenness during specific times of the year in response to seasonal rainfall (Field \& Ross, 1976; Viljoen, 1989b). In savannah habitats, the availability and quality of fodder species are richest during the wet seasons (e.g., monsoons), while they decrease during the winter and are lowest during the dry summer (Owen-Smith, 1988). In Asia, the number of species that are grazed sharply decreases during summer. However, during winter and the monsoon season, the status of browsed species does not change except for a few deciduous forest species (Sukumar, 1989a; Williams, 2003; Pradhan, Wegge, \& Moe, 2007; Pellew, 1984).

Elephants in Asia and Africa are considered to be mixed feeders (Oliver, 1978), whereas most of the other mega-herbivores are grazers (e.g., hippopotami, some rhinoceros species, and buffalos) or browsers (e.g., giraffes and some rhinoceros species) (Baskaran, 1998). However, many researchers have concluded that elephants are generalized feeders (Guy, 1976b), bulk feeders (McNauhton, 1985), coarse feeders (Williamson, 1975), good browsers (Field, 1971; Sukumar, 1990), or even grazers (Chowdhury, 1999; Guy, 1976a). However, due to changing fodder conditions, the feeding strategies of elephants will change with seasonal variations and the availability of fodder species (Baskaran, 1998). During the dry season (e.g., summer), elephants prefer to browse due to a shortage of grasses, while during the wet season (e.g., monsoon), they mostly prefer to graze (Guy, 1976a; Caughley \& Goddard, 1975). During the spring and winter seasons, elephants are either browsers or grazers depending on the availability of forage types (Baskaran, 1998). Elephants mostly feed on natural monocotyledon and dicotyledon plant species. However, occasionally, they switch to domesticated fodder species, such as different crops, vegetables, and fruits with high nutritional content, when natural fodder species present shortages (Sukumar, 1989a; Osborn, 2004). Elephants also choose different parts of fodder species due to their quantities and nutrient varieties (Roy, 2009). For instance, a preference for twigs might vary seasonally, as leaves tend to mature due to their high concentrations of protein sources. Bark, stems, roots, and tubers, on the other hand, are regarded as ample sources of fibre, minerals, and vitamins along with flowers and fruits that supply soluble fat and carbohydrates. Branches and shoots as well as entire plant bodies are considered to be bulky fibre sources which supply sufficient amounts of nutrients (Caughty, 1976; Barns, 1983; Jackman \& Croes, 1991). To maintain continued access to food, elephants cover large home ranges with repeated round trips, and this pattern avoids regrowth and regenerative pressure on fodder species (Sukumar, 1989a; Williams, 2003; Osborn, 1998). Elephants also follow up with a good foraging time to avoid disturbance and conflict with other feeders, including humans (Viljeon, 1989a; Osborn, 2004; Malpas, 1978). Elephants mostly prefer to forage during the early morning, late evening, and during the night, while they rest during the midday in shady locations. The breaking down and removal of unpalatable trees by elephants is a sign of an intelligent feeding strategy that leads to an increase in the number of fodder species within their home range (Jachman $\&$ Bell, 1985; Laws, 1970b; Gadd, 2002). African elephants, both in bushlands as well as in savannahs and Asian elephants 
in forests, practice breaking down of non-fodder trees to increase the opportunity for improved growth of fodder species (Cumming et al., 1997; Jachman \& Bell, 1985; Owen-Smith, 1988; Sukumar, 1989a; Oliver, 1978).

Currently, the elephants in Bangladesh are confined to evergreen and semievergreen hilly forests in two parts of the country, e.g., the southeastern and northwestern parts. However, in previous decades, their range extended to deciduous and floodplain forests over most parts of the country (Sarker, Hossen, \& Røskaft, 2015). We performed our research fieldwork in the TWS, which is located in the southeastern part of the country. This area is a diversified repository for elephants, but it is currently threatened with destruction due to the heavy pressures of different anthropogenic activities in addition to the presence of a large group of Rohingya refugees (who have been arriving from Myanmar) since 2017 (Rahaman, 2018). This sanctuary is connected to the Arakan province of Myanmar and maintains a potential transborder corridor for elephants. However, recently, huge numbers of Rohingya people have shifted along with newly built-up military infrastructures, and the increasing artillery activity on the border between Myanmar and Bangladesh acts to block the elephant migration routes between the two countries (Rahaman, 2018; Hassan, 2017). As a result, the elephants in the sanctuary are confined in a region with a lack of shelter and shortage of food. They are even unable to maintain repeated gaps, which are crucial for their feeding strategy that allows fodder species to regrow and regenerate (Rahman, 2018). The new flow of Rohingya refugees has currently led to the establishment of four major camps with half a million Rohingya people. These camps are set up on forestland with other permitted or illegal settlers (Rahman, 2018). Consequently, the sanctuary has lost most of its elephant roaming grounds and has been converted into a crowded zone that prevents natural elephant movement.

The aim of this study was to monitor the presence of elephants along different transect sites in the sanctuary. At such sites, we recorded the diversification levels of different fodder species in both natural and domesticated transect sites and collected dung samples. Finally, we evaluated which types of ecological factors influence elephant availability across these transect sites, and we discuss the current threats that these elephants face.

\section{Materials and methods}

\subsection{Study Area}

Our field work was conducted in the TWS which is located in the nook and corner of the southern peninsula of Teknaf under Cox's Bazar south forest division (Figure 1), with three ranges and ten beats (Green, 1987; Rosario, 1997). The TWS was recognized as a reserve forest during the British and Pakistan era, and it was turned into a game reserve in 1974 (Rosario, 1997). In 2010, however, it was declared as a wildlife sanctuary (United States Agency for International Deployment [USAID], 2015). The TWS forms a narrow strip that lies between $20^{\circ} 52^{\prime}$ to $21^{0} 09^{\prime} \mathrm{N}$ latitude and $92^{\circ} 08^{\prime}$ to $92^{0} 8^{\prime} \mathrm{E}$ longitude, is straight from north to south with a length of $28 \mathrm{~km}$ and has a $3.5 \mathrm{~km}$ breadth in the east-west direction (Rosario, 1997; Mukul, 2007) (Figure 1). On the east coast, it is confined by the Naf River and on its west coast by the Bay of Bengal (Sarker et al., 2015; Hassan, 2017). The TWS is $82 \mathrm{~km}$ away from Cox's Bazar district and encompasses a 11,615-ha hilly area out of a total of 551,000 ha of hill forest (Department of Environment [DoE], 2012; Sharma \& Yonzon, 2005) and is delineated by 10 blocks, with 6 on the east coast and 4 on the west coast (Bari \& Dutta, 2004). The topographical features of the TWS are characterized by rocks from the Pliocene and Miocene Epochs, which belong to the three geographical series of Surma, Tipam, and Dhupitila in the Indo-Chinese subregion (Choudhury, 1969; DoE, 2012). The sanctuary features undulating hills and hillocks with sharp and gentle slopes with numerous valleys and precipitous networks of several large and small perennial and ephemeral streams; notably, seven large perennial streams flow down to the east coast of the Naf River and four to the Bay of Bengal (Bari \& Dutta, 2004; USAID, 2015). The soil types of the TWS consist of clay to clay-loam, silty to silty-loam, and fine sand on the east coast and sandy, sandy coarse, granular, and crumbs on the west coast (Choudhury, 1969). The highest altitude in the sanctuary is 700 feet and discharges large amounts of water during the monsoon season (Bari \& Dutta, 2004). In the TWS, the meteorological parameters (e.g., temperature, rainfall, moisture, and tropical storms) vary with season. The annual average recorded rainfall is $1017 \mathrm{~mm}$ (Bangladesh Meteorological Department [BMD], 2019). The minimum spring temperature is $20.8^{0} \mathrm{C}$, and the maximum temperature during the monsoon season is $32.1^{0} \mathrm{C}$ (Bari \& Dutta, 2004; Hassan, 2017; BMD, 2019). The humidity during spring exhibits a minimum of 27.6\% and maximum of 98\% (Bari \& Dutta, 2004; Hassan, 2017; BMD, 2019). Tropical storms mainly impact the TWS during May and November (Bari \& Dutta, 2004; BMD, 2019).

The TWS is renewable and is enriched by biological diversity and even maintains ecologically significant value in the hilly terrain of the southeastern part of the country (Nishat, Huq, Barua, Khan, \& Moniruzzaman, 2002). This sanctuary now contains 535 angiosperm species that belong to 370 genera and 103 families (Uddin, Alam, \& Hassan 2012; Manan, 2006) and 142 tree species, 112 shrubs, 184 herbs, 87 climbers, 10 epiphytes, and one parasitic species are present in the sanctuary (Uddin et al., 2012). In addition, the TWS contains 27 amphibian species, 54 reptilian species, 243 avian species, and 43 mammal species (Islam, Miah, \& Habib, 2013; Khan, 2008; International Union for Conservation of Nature [IUCN], 2015). Charismatic megaherbivore elephants roam with rare primates such as the Bengal slow loris 
(Nycticebus bengalensis) and crabeater monkeys (Macaca fascicularis), along with critically endangered cat species such as golden cats (Catopuma temminckii), fishing cats (Prionailurus viverrinus), and jungle cats (Felis chaus) (Khan, 2008; Sarker et al., 2015). The TWS is a more specialized sanctuary than the other 20 sanctuaries in the country, which are sporadically distributed (DoE, 2012).

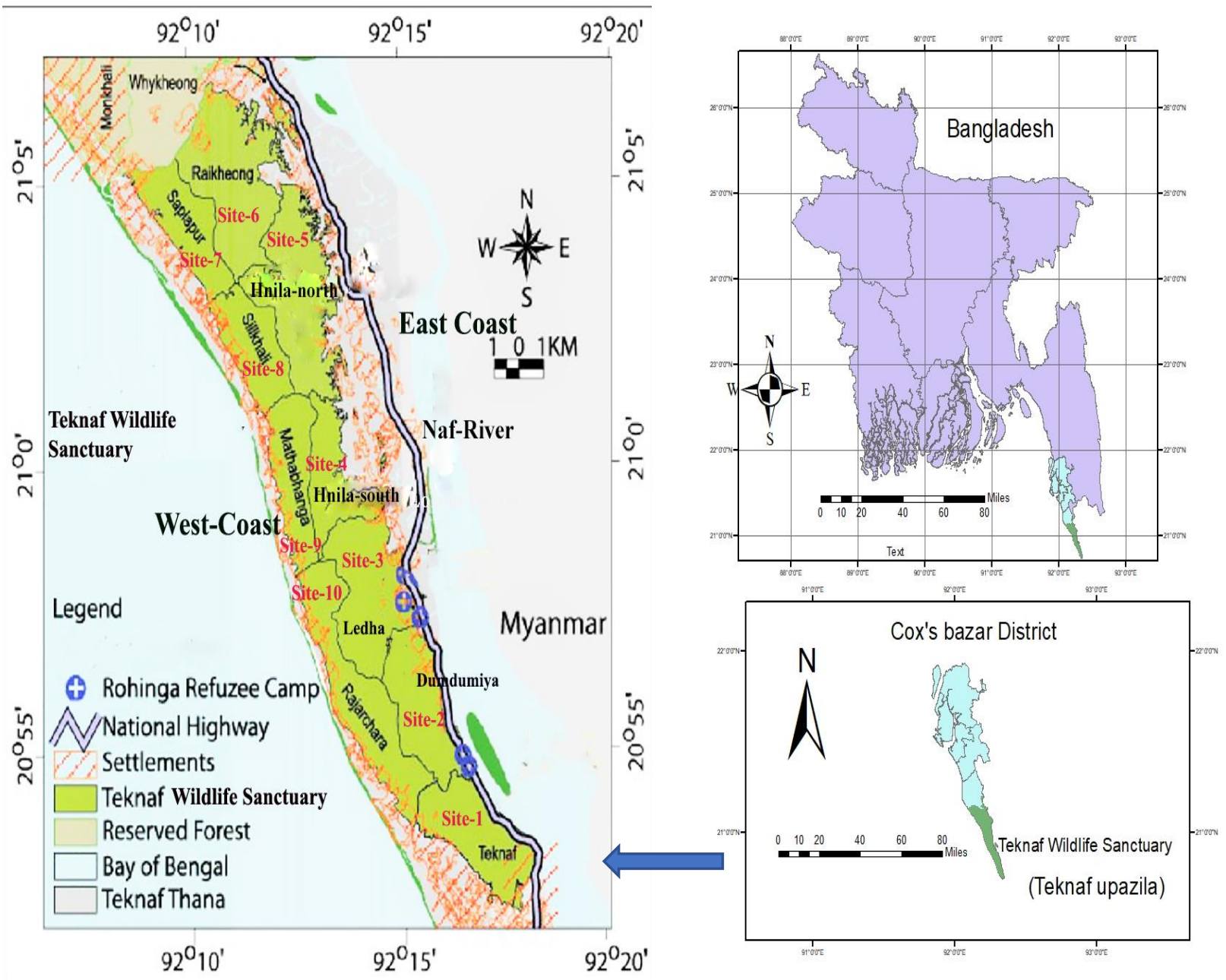

Figure 1. Teknaf Wildlife Sanctuary under Cox's Bazar district, south forest division, with ten transect sites, including site-1 (Teknaf), Site-2 (Dumdumiya), Site-3 (Ledha), Site-4 (Hnila-south), Site-5 (Hnila-north), Site-6 (Raingkhali),

Site-7 (Saplapur), Site-8 (Shilkhali), Site-9 (Mathabanga) and Site-10 (Rajarchara)

\subsection{Data Collection Methods}

Our data collection efforts were based on field observations with a fixed number of monthly working days (5 days) from August 2018 to July 2019. We established ten transect sites in the TWS from the west coast to east coast (Figure 1). Ten research assistants, as well as two research adjuncts, were employed to smoothly manage the year-bound research work across the 10 sites. First, by the use of high-power binoculars (Bushnell 20×70 optical zoom), we completed live elephant observations at risk-free distances to observe their feeding behaviours. We observed which plant species the elephants were eating, including which parts of plants were consumed as food by the elephants. After completing an observation, we identified the consumed plant species by use of a field notebook and information regarding Bangladeshi flora. A local expert field assistant who was sufficiently knowledgeable of plant varieties was employed for this data collection. In addition, we used a mobile telephone app (Plant Snap) to assist with field identifications. For quality assurance as well as cross-checking, we took photos of all plants that were eaten by elephants and preserved consumed plant specimens for later verification in the national herbarium for taxonomic identification. We used a tag for each specimen to ensure that the field and laboratory identifications were identical. When the tags were similar for both identification methods, we accepted these identifications as recorded species. However, for cases of dissimilarity $(\mathrm{N}=17)$, the laboratory identification was given priority for species identification. We mainly adopted ground-truthing direct observations of foraging elephant herds or single individuals, but on a few occasions, we also used indirect observations, such as 
previously eaten, broken, debarked, or uprooted plants or plant parts, as well as dung-pile dissection techniques to identify elephant fodder. We dissected a total of 250 dung piles across the 10 transect sites, with 25 from each site. After we collected these fragments, they were sent to the lab for taxonomic identification. After we verified the fodder species used by elephants and we were satisfied with the number of elephants foraging behaviour observations $(\mathrm{N}=50 ; 5$ in each site), we applied a line-transect survey that included ten observation sites to record the site-based numbers of available fodder species as well as the no-fodder species (Figures 1,2). We avoided any redundancy during our recording of potential fodder species. Within the ten transects, we completed a total of 36 line transects $(100 \mathrm{~m} \times 10 \mathrm{~m})$ within each transect site in which we equally considered hilltops, slopes, valleys, and even plainlands. We therefore recorded 360 smaller sites within the ten transect sites with fixed-sized quadrate blocks $(7 \mathrm{~m} \times 7 \mathrm{~m}$ ) in each transect (Figure 2). We were able to use 108 smaller sites from each transect site, and summarised up to 1080 sites across the ten transects (Figure 2). In addition to utilizing fodder species (recorded by elephant observations), we also recorded species that were not utilized by elephants (non-fodder species). We initially collected information from the illegal and endorsed settlers as well as from villagers living close to the forests (nearest forest) who were mostly engaged in agricultural practices using domesticated fodder species, such as cultivated crops, vegetables, and homestead garden plants. We were then generally able to determine the domesticated fodder species in the dung samples based on the information provided by these settlers. Finally, we recorded a number of crops, vegetable, and especially fruit tree varieties, as domesticated fodder species through several field-based observations. Our site research correspondents also helped to record, through continuous checks across sites, the varieties that were frequently consumed by elephants. We recorded domesticated fodder species by using only field-level identifications. The presence of elephants in the sanctuary is not only influenced by fodder species but is also dependent on a number of other key ecological factors. We therefore identified most of these dominant ecological factors that are utilized by elephants, including waterbodies, resting places, movement trails, and soil types. Quantity data were collected from the identified dominant ecological factors to assess their physiological features regarding site quality.

\subsection{Data Analysis Methods}

For the data analyses, we used various software packages, such as biological diversity calculation software, SPSS software version 26 (IBM Corp, Chicago, USA), ArcGIS software version 10.7.1 (Esri, California, USA), and Adobe Photoshop software. We used different software products to analyse our datasets for comparison, differentiation, and uniformities and finally, we constructed graphical and tabular representations as outputs. We calculated five types of diversity indices (e.g., Shannon's index, Simpson's index, dominance index, richness, and evenness indices) with the aid of biological diversity calculation software to assess fodder species abundances across sites, as well as site quality. By using SPSS software, we combined multifold statistical analyses with descriptive statistics, comparative statistics and inferential statistics. We used the mean \pm SD to determine a variable's average value and used a statistically significant value of $\mathrm{P} \leq 0.05$. Finally, we used ArcGIS and Photoshop software to construct site maps.

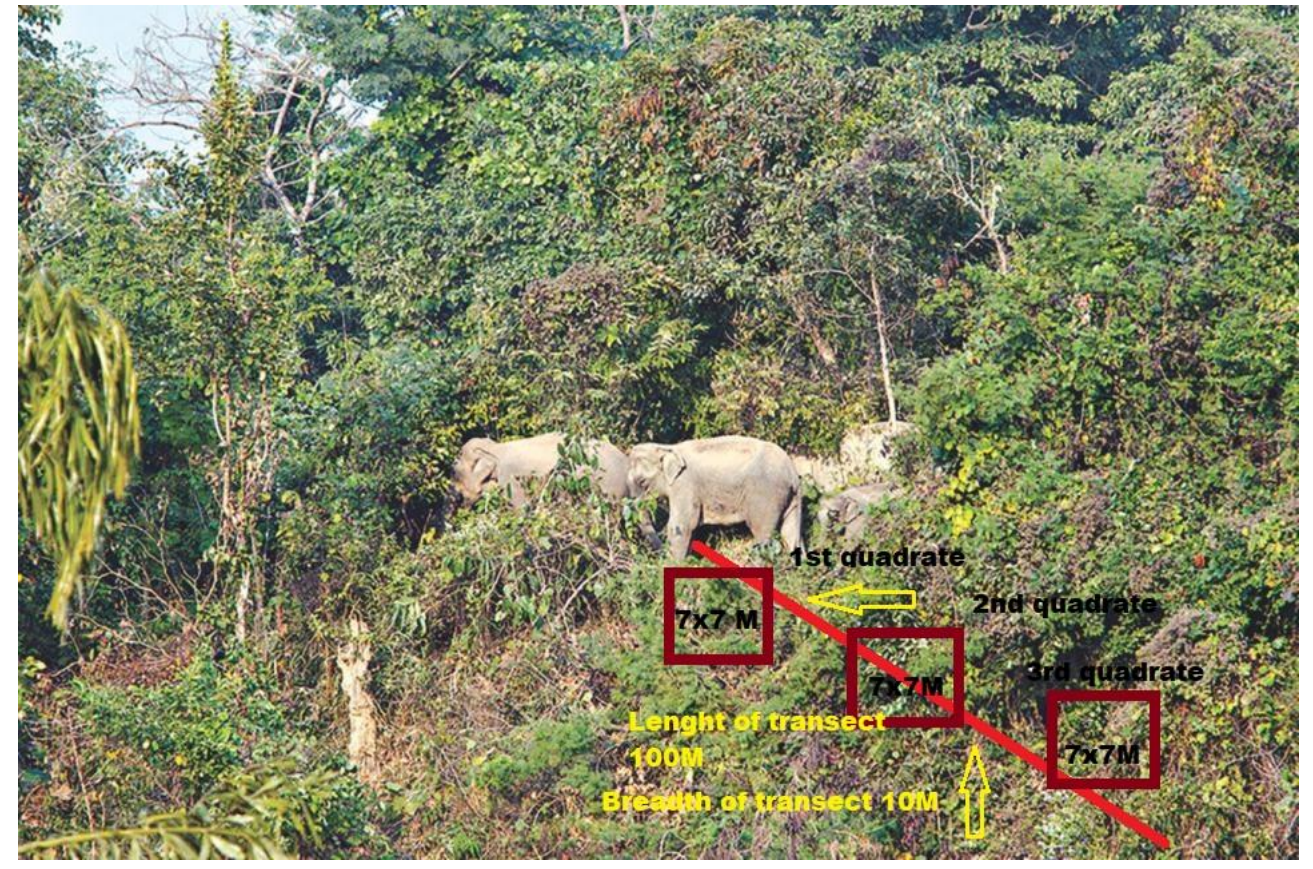

Figure 2. Schematic diagram of a transect line with quadratic sample sites in the TWS. Each transect included 36 small quadratic sample sites where all plants were recorded 


\section{Results}

A total of 184 fodder species were recorded in elephant faeces, which included 129 natural species, such as monocotyledons $(\mathrm{N}=71)$ and dicotyledons $(\mathrm{N}=58)$. In addition, 55 domesticated species were recorded, which included cultivated crops $(\mathrm{N}=13)$, cultivated vegetables $(\mathrm{N}=24)$ and homestead garden plants $(\mathrm{N}=18)$ (Table 2). Elephants feed on different parts of fodder species, including the leaves, twigs, stems, branches, roots, tubers, bark, shoots, flowers, fruits, saplings, and seedlings. Frequently, they choose two or more, and occasionally, they choose to eat entire plants.

The number of natural fodder species varied significantly among the ten transect sites $(F=2.28, \mathrm{df}=9, \mathrm{P}=0.022)$, while the number of non-fodder species did not vary significantly among the transect sites $(\mathrm{F}=0.925, \mathrm{df}=9, \mathrm{P}=0.507)$. However, different numbers of fodder and non-fodder species were found for different transect sites (Table 1). Fodder species (mean $=3.09 \pm \mathrm{SD} 2.14)$ abundances varied with non-fodder species (mean $=8.62 \pm \mathrm{SD} 5.61)$ abundance $\left(\mathrm{R}^{2}=\right.$ $0.470, y=0.93+0.26 x, P<0.0001)$. Furthermore, the number of recorded elephants feeding trails varied significantly among sites $\left(\chi^{2}=35.7, \mathrm{df}=9, \mathrm{P}<0.0001\right.$; Table 1$)$. However, no significant differences between the number of elephant trails were found between the east and west coasts $\left(\chi^{2}=1.259, \mathrm{df}=1, \mathrm{P}=0.262\right)$.

The monocotyledon diversity on the ground was higher (39\%) than that of dicotyledons (31\%) and domesticated plants (30\%). In dung piles, dicotyledons (40\%) were more common than monocotyledons (34\%) and domesticated plants (26\%) (Table 2). The relationships among ground fodder species including monocotyledons (mean $=0.92 \pm$ SD 0.97), dicotyledons (mean $=1.02 \pm \mathrm{SD} 0.93$ ), domesticated (mean $=0.87 \pm \mathrm{SD} 0.89)$ and those found in dung piles including monocotyledons (mean $=0.52 \pm$ SD 0.72), dicotyledons, $($ mean $=0.62 \pm$ SD 0.67), domesticated $($ mean $=0.48 \pm$ SD 0.64) were not statistically significant $\left(\chi^{2}=30.4, \mathrm{df}=35, \mathrm{P}=0.690\right.$; Table 1$)$. A statistically significant difference was found between ground monocotyledons and dung-pile monocotyledons $\left(\chi^{2}=26.2, \mathrm{df}=12, \mathrm{P}=0.010\right)$, but no significant differences were found between ground dicotyledons and dung-pile dicotyledons $\left(\chi^{2}=6.06, \mathrm{df}=6, \mathrm{P}=0.416\right)$ or between ground domesticated and dung-pile domesticated species $\left(\chi^{2}=5.057, \mathrm{df}=6, \mathrm{P}=0.537\right)$ (Table 1). Moreover, the differences between the ground monocotyledons and dung piles dicotyledons $\left(\chi^{2}=16.9\right.$, $\mathrm{df}=8, \mathrm{P}=0.030$ ) were statistically significantly different, but there were no significant differences with the domesticated dung pile species $\left(\chi^{2}=\right.$ 7.29 , $\mathrm{df}=8, \mathrm{P}=0.505$ ) (Table 1). There were no statistically significant differences between ground dicotyledons and dung-pile monocotyledons $\left(\chi^{2}=1.96, \mathrm{df}=9, \mathrm{P}=0.992\right)$ or dung-pile domesticated species $\left(\chi^{2}=3.50, \mathrm{df}=6, \mathrm{P}=0.744\right)$ (Table 1). The differences between ground domesticated and dung-pile monocotyledon species $\left(\chi^{2}=9.82, \mathrm{df}=9, \mathrm{P}=\right.$ 0.365 ) or between dung-pile dicotyledon species $\left(\chi^{2}=1.09, \mathrm{df}=6, \mathrm{P}=0.982\right)$ were not statistically significant (Table 1 ). A statistically significant difference was found between sites and ground monocotyledon species $((\mathrm{F}=3.188, \mathrm{df}=9, \mathrm{P}=$ $0.002)$ as well as between dicotyledons $(\mathrm{F}=2.213, \mathrm{df}=9, \mathrm{P}=0.026)$, but no significant differences were found between domesticated species $(\mathrm{F}=.761, \mathrm{df}=9, \mathrm{P}=0.652)$ (Table 1$)$. The differences between sites and dung-pile monocotyledons were statistically significant $(\mathrm{F}=2.213, \mathrm{df}=9, \mathrm{P}=0.026)$ but not between dicotyledons $(\mathrm{F}=1.405, \mathrm{df}=9, \mathrm{P}=0.195)$ or even domesticated species $(\mathrm{F}=1.115, \mathrm{df}=9, \mathrm{P}=0.358)$ (Table 1).

The Shannon index values were statistically significantly different among the three types of fodder species and between the ground and dung piles $\left(\chi^{2}=31.27, \mathrm{df}=2, \mathrm{P}<0.0001\right.$; Table 2$)$. The Shannon index values were statistically significantly different between monocotyledons and dicotyledons on the ground $(\mathrm{F}=2.145, \mathrm{df}=7, \mathrm{P}<0.05)$ and between dicotyledons and domesticated plants $(\mathrm{F}=2.145, \mathrm{df}=7, \mathrm{P}<0.05)$. The differences between monocotyledons and domesticated were, however, not statistically significant $(\mathrm{F}=1.25$, $\mathrm{df}=7, \mathrm{P}=0.291$; Table 2). Furthermore, the differences in Shannon index values between monocotyledons and dicotyledons in dung piles were statistically significant $(\mathrm{F}=3.08, \mathrm{df}=6, \mathrm{P}=0.017)$, while the differences between dicotyledons and domesticated plants were nearly statistically significant $(\mathrm{F}=2.168, \mathrm{df}=5, \mathrm{P}=0.082)$. However, no significant differences $(\mathrm{F}=0.784, \mathrm{df}=6, \mathrm{P}=0.589)$ were found between monocotyledons and domesticated plants (Table 2). The Simpson index of different fodder types among transects was found to vary significantly among fodder types on the ground (monocotyledons $\chi^{2}=30.33, \mathrm{df}=12$, $\mathrm{P}=0.002$; dicotyledons; $\chi^{2}=23.88, \mathrm{df}=8, \mathrm{P}=0.003$ and domesticated plants; $\left.\chi^{2}=30.00, \mathrm{df}=10, \mathrm{P}<0.001\right)$. In dung piles, the Simpson index values differed significantly among fodder species types, which included dicotyledons $\left(\chi^{2}=\right.$ 17.87, $\mathrm{df}=8, \mathrm{P}=0.022)$ and domesticated plants $\left(\chi^{2}=28.43\right.$, $\left.\mathrm{df}=8, \mathrm{P}<0.0001\right)$, while they were not significantly different among monocotyledons $\left(\chi^{2}=15.95, \mathrm{df}=10, \mathrm{P}=0.101\right.$; Table 2$)$ 
Table 1. Number of different plant species found on the ground and in elephant dung piles for the ten different transects

\section{Monocotyledons Dicotyledons Domesticated plants Others}

\begin{tabular}{|c|c|c|c|c|c|c|c|c|c|c|c|c|c|}
\hline & Site names & $\begin{array}{l}\vec{\Xi} \\
0 \\
0\end{array}$ & 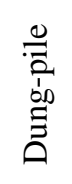 & 萢 & $\begin{array}{l}\vec{\Xi} \\
\text { 苞 } \\
\end{array}$ & 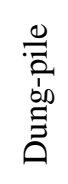 & ] & $\begin{array}{l}\vec{\Xi} \\
\text { 苞 }\end{array}$ & 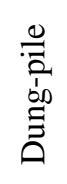 & 胥 & 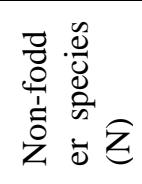 & 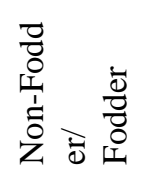 & 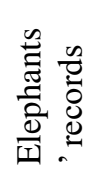 \\
\hline \multirow{6}{*}{ 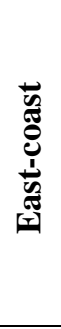 } & Site-1 & 12 & 6 & 18 & 16 & 7 & 23 & 11 & 4 & 15 & 94 & 2.29 & 4 \\
\hline & Site-2 & 25 & 10 & 35 & 14 & 8 & 22 & 6 & 2 & 8 & 124 & 2.17 & 16 \\
\hline & Site-3 & 7 & 4 & 11 & 6 & 7 & 13 & 9 & 8 & 17 & 85 & 3.54 & 2 \\
\hline & Site-4 & 12 & 7 & 19 & 7 & 3 & 10 & 12 & 7 & 19 & 100 & 3.44 & 5 \\
\hline & Site-5 & 6 & 2 & 8 & 12 & 6 & 18 & 16 & 6 & 22 & 75 & 2.88 & 6 \\
\hline & Site- 6 & 7 & 8 & 15 & 15 & 8 & 23 & 10 & 4 & 14 & 112 & 2.94 & 9 \\
\hline \multirow{4}{*}{ 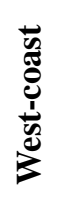 } & Site-7 & 11 & 6 & 17 & 6 & 5 & 11 & 15 & 10 & 25 & 105 & 3.75 & 3 \\
\hline & Site- 8 & 8 & 5 & 13 & 12 & 9 & 21 & 11 & 5 & 16 & 90 & 2.64 & 7 \\
\hline & Site-9 & 12 & 8 & 20 & 16 & 7 & 23 & 9 & 6 & 14 & 115 & 2.67 & 10 \\
\hline & Site-10 & 11 & 7 & 18 & 18 & 13 & 21 & 4 & 6 & 10 & 104 & 2.12 & 5 \\
\hline
\end{tabular}

Note: *Recorded natural fodder species (129), *Domesticated fodder species (55)* Ratios are mentioned only among natural fodder and non-fodder species *Number of elephants based on observations during field visits

Table 2. Biological diversity indices of three categories of elephant fodder species both on the ground and in dung piles

\begin{tabular}{lcccccc} 
& Ground & Ground & Ground & Dung piles & Dung piles & Dung piles \\
\cline { 2 - 7 } $\begin{array}{l}\text { Diversity } \\
\text { indices }\end{array}$ & Monocotyledon & Dicotyledon & Domesticated & Monocotyledon & Dicotyledon & Domesticated \\
$\begin{array}{l}\text { Recorded } \\
\text { Species (N) }\end{array}$ & 71 & 58 & 55 & 36 & 42 & 27 \\
$\begin{array}{l}\text { Recorded } \\
\text { Families (N) }\end{array}$ & 14 & 26 & 20 & 12 & 18 & 9 \\
$\begin{array}{l}\text { Shannon } \\
\text { Index }\end{array}$ & 1.92 & 3.02 & 2.69 & 2.11 & 2.69 & 2.00 \\
$\begin{array}{l}\text { Simpson } \\
\text { index }\end{array}$ & 0.22 & 0.04 & 0.07 & 0.13 & 0.06 & 0.12 \\
$\begin{array}{l}\text { Dominance } \\
\text { index }\end{array}$ & 0.77 & 0.95 & 0.92 & 0.87 & 0.93 & 0.87 \\
$\begin{array}{l}\text { Richness } \\
\text { index }\end{array}$ & 3.05 & 6.15 & 4.74 & 3.07 & 4.55 & 2.43 \\
$\begin{array}{l}\text { Evenness } \\
\text { index }\end{array}$ & 0.73 & 0.93 & 0.89 & 0.85 & 0.92 & 0.96 \\
\hline
\end{tabular}

The Lorenz curves for monocotyledon, dicotyledon, and domesticated fodder species both on the ground and in dung piles represent the cumulative proportions of the total population size (Figure 3). The deviation rates from the Lorenz curve (blue curved lines in Figure 3) line of equality (black straight lines in Figure 3) indicate the fodder species population size. On the ground, the Lorenz curve of monocotyledons deviated prominently from the line of equality and was an indicator of a larger population size (Figure 3A). The deviation between the line of equality and the Lorenz curve for dicotyledons indicated a moderate population size (Figure 3B). For the domesticated fodder species, the deviation between the line of equality and Lorenz curve indicated a larger population size than for the dicotyledons but less than of monocotyledons (Figure 3C). The population size of monocotyledons in dung piles was an indicator of a healthy population by measuring the type of deviation between the line of equality and the Lorenz curve (Figure 3D). The population size of dicotyledons was found to be poorly moderated by an assessment of the deviation between the line of equality and the Lorenz curve (Figure 3E). The population size of the domesticated fodder species was found to be 
healthy by measuring the deviation between the line of equality and Lorenz curve (Figure 3F).

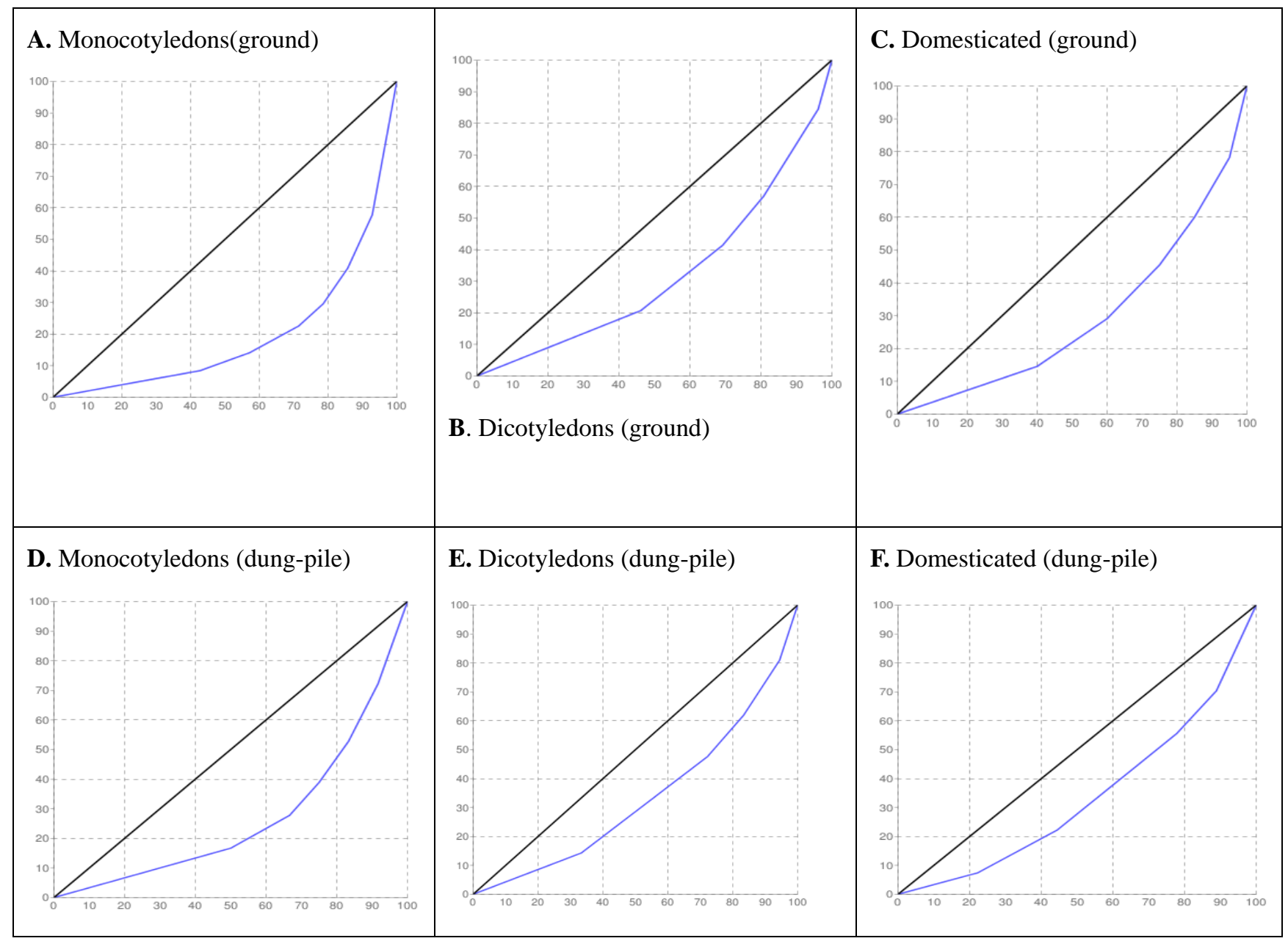

Figure 3. Lorenz curves, which indicate population sizes, of monocotyledons, dicotyledons, and domesticated fodder species both on the ground (A-C) and in dung piles (D-F) with a range from 0 to 100 individuals on the $\mathrm{X}$ and $\mathrm{Y}$ axes

The variations in the number of natural fodder species across transect sites were statistically significant $(\mathrm{F}=2.522, \mathrm{df}=9$, $\mathrm{P}=0.011)$, but the variations in elephant observations across sites was not statistically significant $(\mathrm{F}=1.302, \mathrm{df}=9, \mathrm{P}=$ $0.244)$. The differences in elephant density and natural fodder species density (per square kilometre) were statistically significant $\left(\chi^{2}=73.705, \mathrm{df}=55, \mathrm{P}=0.047\right)$. Across sites, the natural fodder species relationships with illegal settlers $(\mathrm{r}=$ $-.314, \mathrm{P}=0.377)$, endorsed settlers $(\mathrm{r}=-.310 \mathrm{P}=0.383)$ and year-round number of intruders $(\mathrm{r}=-.204, \mathrm{P}=0.572)$ were nonsignificant. The relationship of elephant densities to illegal settlers $(r=-.636, P=0.048)$ were significantly negatively correlated, while the relationship with endorsed settlers was only nearly statistically significant $(\mathrm{r}=-.588, \mathrm{P}=0.074)$. The relationship with the number of intruders per square kilometre was nonsignificant $(r=-.097 \mathrm{P}=0.791)$. 
Table 3. Density of natural fodder species, elephant density, illegal settler density, endorsed settler density and year-round intruder density per square kilometre across the transects in the TWS

\begin{tabular}{|c|c|c|c|c|c|c|c|c|c|c|}
\hline $\begin{array}{l}\text { Density per } \\
\mathbf{k m}^{2}\end{array}$ & Site-1 & Site-2 & Site-3 & Site-4 & Site-5 & Site-6 & Site-7 & Site-8 & Site-9 & Site10- \\
\hline $\begin{array}{l}\text { Natural fodder } \\
\text { species density }\end{array}$ & 3.40 & 5.52 & 1.91 & 3.46 & 1.51 & 2.14 & 3.34 & 4.47 & 5.03 & 3.62 \\
\hline $\begin{array}{l}\text { Elephants' } \\
\text { density }\end{array}$ & 0.33 & 1.55 & 0.15 & 0.59 & 0.34 & 0.50 & 0.35 & 0.92 & 1.17 & 0.36 \\
\hline $\begin{array}{l}\text { Illegal settler's } \\
\text { density }\end{array}$ & 101.07 & 19.28 & 122.37 & 150.35 & 62.28 & 39.16 & 142.60 & 60.86 & 56.32 & 89.49 \\
\hline $\begin{array}{l}\text { Endorse } \\
\text { settler's density }\end{array}$ & 12.45 & 5.81 & 15.92 & 11.96 & 6.97 & 7.90 & 20.88 & 5.27 & 8.19 & 9.61 \\
\hline $\begin{array}{l}\text { Year-round } \\
\text { intruders' } \\
\text { density }\end{array}$ & 295.84 & 84.49 & 198.56 & 364.35 & 169.20 & 136.23 & 431.86 & 294.99 & 397.30 & 176.92 \\
\hline
\end{tabular}

The presence of elephants (e.g., yes or no) in different patches varied statistically and significantly with waterbodies, resting places and soil types and nonsignificant with fodder species and movement trials (Table 4). The presence of elephants showed statistically significant differences among the transect sites $\left(\chi^{2}=35.75, \mathrm{df}=9, \mathrm{P}<0.0001\right)$, but no differences were found between elephant presence between the east and west coasts $\left(\chi^{2}=1.259\right.$, $\left.\mathrm{df}=1, \mathrm{P}=0.262\right)$. Additionally, a strong statistically significant difference was found between the presence of elephants and dung-pile availability $\left(\chi^{2}=46.84\right.$, df $\left.=9, \mathrm{P}<0.0001\right)$. Furthermore, statistically significant differences were found between dung-pile availability to waterbodies, as well as for resting places and movement trails, but nonsignificant differences were found between the dung-pile availability of fodder species and soil types across sites (Table 5). Statistically significant differences were also found among waterbodies and soil types $\left(\chi^{2}=24.27, \mathrm{df}=9, \mathrm{P}<0.0001\right)$, among feeding trails and fodder species $\left(\chi^{2}=106.9, \mathrm{df}=50, \mathrm{P}<0.0001\right)$, among resting places and waterbodies $\left(\chi^{2}=54.75, \mathrm{df}=9, \mathrm{P}<\right.$ 0.0001 ), among resting places and feeding trails $\left(\chi^{2}=44.36, \mathrm{df}=15, \mathrm{P}=0.020\right)$ and among fodder species and waterbodies $\left(\chi^{2}=42.13, \mathrm{df}=30, \mathrm{P}=0.05\right.$ ) (Table 5).

Table 4. Binary logistic regression analyses with elephant availability (e.g., present or absent) as the response variable against five ecological factors as independent variables

\begin{tabular}{|c|c|c|c|c|c|c|}
\hline Independent variables & B & S. E & Wald & df & $\mathbf{P} \leq$ & $\operatorname{Exp}(\mathbf{B})$ \\
\hline $\begin{array}{l}\text { Fodder species } \\
\text { (yes or no) }\end{array}$ & .170 & .134 & 1.619 & 1 & .203 & 1.186 \\
\hline $\begin{array}{l}\text { Waterbodies } \\
\text { (yes or no) }\end{array}$ & 1.028 & .431 & 5.701 & 1 & .017 & 2.797 \\
\hline $\begin{array}{l}\text { Resting places } \\
(\mathrm{N}=257)\end{array}$ & 1.793 & .520 & 11.881 & 1 & .001 & 6.005 \\
\hline $\begin{array}{l}\text { Movement trails } \\
\text { (Feeding trails) }\end{array}$ & .034 & .300 & .013 & 1 & .911 & 1.034 \\
\hline Soil types $(\mathrm{N}=4)$ & -.733 & .353 & 4.324 & 1 & .038 & . 480 \\
\hline Constant & -4.069 & 1.269 & 10.277 & 1 & .001 & .017 \\
\hline
\end{tabular}

Note: *Cox \& Snell $\mathrm{R}^{2}=.351 *$ Nagelkerke $\mathrm{R}^{2}=.469$ 
Table 5. One-way multivariate analysis (MANOVA) with dung-pile numbers as the dependent variable and five ecological factors as independent variables

\begin{tabular}{llll}
\hline Independent variables & df & F -value & P $\leq$ \\
\hline Fodder species & 9 & 4.032 & .541 \\
Waterbodies & 9 & 1.868 & $\mathbf{. 0 0 0 1}$ \\
Resting places & 9 & 3.457 & $\mathbf{. 0 0 0 1}$ \\
Movement trails & 9 & 2.578 & $\mathbf{. 0 0 4}$ \\
Soil types & 9 & 1.117 & .070 \\
\hline
\end{tabular}

\section{Discussion}

The relationships among elephants and fodder species in an area with a certain habitat and not just the composition of fodder species, but also emphasizes the essential survivability of elephants in terms of food, is considered to be the crucial requirement for any kind of life (Jackman \& Bell, 1985). Therefore, the availability of elephants in an area is balanced with the prime fodder species in the same area, as they play a necessary role in elephant survival (Daniel, 1980). Thus, no fodder species in a habitat reflects that an elephant presence would not be possible in that habitat (Osborn, 2004). Our findings indicated that there was a total of 184 fodder species, of which 129 were from families that naturally occurred in forests. These fodder species belong to 40 different families and include monocotyledons $($ species $=71$, families $=14$ ) and dicotyledons ( species $=58$, families $=26$ ). Except for the natural fodder species, elephants were using 55 different domesticated fodder species that belonged to 20 families of monocotyledons and dicotyledons. In the dung piles, we recorded 78 natural fodder species that belonged to 30 different families and included monocotyledons (species $=36$, families $=12$ ) and dicotyledons ( included 9 families of monocotyledons and dicotyledons. The diversity in the recorded dung piles never exceeded the diversity that was recorded on the ground. Therefore, many different species of fodder plants were found to be in the elephant diet, which mostly consisted of monocotyledons and dicotyledons. Similar findings have been observed in two neighbouring countries, Myanmar and India, both of which are interconnected with Bangladesh by land borders. Himmelsbach, Tagle, Fuldner, Hoefle, \& Htun (2006) recorded 124 fodder species of monocotyledons and dicotyledons in elephant diets in Myanmar. However, Karunaratnes \& Ranawana (1999) recorded 112 elephant fodder species in fewer families, such as Arecaceae, Leguminoseae, Malvace, and Gramine. This finding is strikingly similar to the findings of Sukumar (1990) who found that elephants consumed 112 plant species. He found that $85 \%$ of the elephant diet consisted of only 25 recorded fodder species out of the total of 112 recorded species. Additionally, Pradan et al. (2007) recorded 62 fodder species out of a potential number of 85 in different forest types in Bardia National Park, Nepal. Closely related research was carried out in Parsa Wildlife Reserve in Nepal by Yadav, Dutta, Chalise, Williums, \& Sharma, (2013) and found 34 fodder species out of a potential 133 species. Distinct research that was conducted by De Boer, Ntumi, Correia, \& Mafuca (2000) on African elephants in the Maputo Elephant Reserve, Mozambique, Africa, recorded 95 fodder species, of which $66 \%$ were browsing and $34 \%$ were grazing species, which consisted of trees, shrubs, herbs, climbers, and grasses. De Boer et al. (2000) underlined that the relative concentrations of fodder species differed by habitat type. African elephants have commonly been determined to eat more than 100 different woody plants species and a lesser variety of grasses, but this variation is sometimes regulated by fire, rainfall, soil quality, temperature, grazing, and browsing pressure (Guy, 1976a). Furthermore, Williamson (1975) recorded that the diet of elephants in Hwange National Park, Zimbabwe consisted almost entirely of woody plant species, while Laws et al. (1975) reported that elephants in Uganda mostly relied $90 \%$ on grasses. Finally, Codron et al. (2006) recorded a difference between the northern and southern elephant populations in South Africa, where the northern population depended on grasses while the southern population consisted of browsers. As found in our study, elephants are not strictly dependent on natural fodder species, and they sometimes switch to domesticated species such as crops, fruits, and vegetables due to their higher fibre, protein, and mineral concentrations than those of natural fodder species (Baskaran, 1998; Mckay, 1973). As addressed by Sukumar (1990) elephants in hilly habitats in India were attracted by rain-fed crops (e.g., paddy, wheat, sorghum, and sugarcane), perennial and semi-perennial homestead garden plants (e.g., trees and fruits of mango and jackfruit) and seasonally oriented vegetables (e.g., different gourds and beans). Our results were also similar, as the most desirable fruits for elephants were jackfruits and mango, both green and ripe paddy crops and watermelons, as well as leafy succulent vegetables and different types of gourds. The preferences and switches toward domesticated fodder species depend on the coverage range and availability of the different types of domesticated fodder species (Graham, Douglas-Hamilton, Adams, $\&$ Phyllise, 2009). Our findings are in accordance with Roy's (2009) findings in the Buxa Tiger Reserve, India, where they revealed that the crude protein and mineral concentrations were higher in domesticated fodder species than in natural fodder species.

Habitat characteristics are regulated by a number of ecological factors with the biological, chemical, and physiological interactions ensuring balanced ecological services (Viljeon, 1989b). According to Baskaran (1998) a particular habitat is 
used by elephants, and the density of elephants per unit area of a forest depends on the health conditions of all ecological factors. Our results indicate that fodder species, water bodies, resting places, feeding trials, and soil types are the dominant ecological factors that determine the presence of elephants in the TWS. The number of fodder species, both on the ground and in dung piles, was found to be diversified among sites with respect to the variations in site qualities. The ratios between ground and dung-pile-recorded fodder species were found to vary between 45:26 and 22:14. As addressed by Sukumar (1990) elephants consumed different parts of fodder species, which varied among different seasons and even among different forests and were related to the types and quantities of nutrients. Nutrient demands also vary with the sex and age of elephants along with daily demands (Stokke, 1999; De Boer et al., 2000). Our findings support the view that elephants in the sanctuary consumed different parts of fodder species consisting of leaves, twigs, branches, stems, roots, barks, shoots, flowers, fruits, and tubers. Codron et al. (2006) discussed the fact that the present density of elephants across a range of habitats depends on the quality of ecological factors in response to daily activities and movement patterns. Ecological factors also act as a limiting factor in elephant habitats, which determine the presence or absence of elephants (Sukumar, 1990; Guy, 1976b; De Boer et al., 2000). Our findings showed that the elephant presence rates across sites were significantly correlated with the availability of water bodies, disturbance-free resting places, and feeding trails. We also found a significant relationship between soil types and elephant presence across sites. According to Jackson, Manwaring \& Caldwell (1990) soil types govern forage quality by circulating nutrient cycles together with maintaining water volumes and moisture concentrations. Soil water and moisture concentrations play vital roles in regulating the fibrous concentrations of grasses, forbs, and woody plants, which are all important for elephant digestibility (Clegg \& O’Connor, 2012). As discussed by du Toit et al. (1990) granite and sedimentary soils govern the low fibre and high protein concentrations of woody plants, and igneous soils maintain low nutrient concentrations rather than sedimentary soil. As ecological components are regarded as basic components of habitats for ensuring the presence of any type of wildlife, all anthropogenic disturbances must be minimized to protect the main features of the ecological factors (Douglas-Hamilton, Krink, \& Vollrath, 2005). We recorded two types of water bodies, perennial and ephemeral, as well as four soil types, namely, clay, sandy, mixed clay-sandy, fine and coarse clay-sandy, and resting places and feeding trails in different locations across sites. According to Wittemyer, Getz, Vollrath \& Douglas-Hamilton (2007) elephants prefer to spend leisure time near water bodies, and they choose resting places and feeding trails that are near water bodies during the dry season. The mean density of fodder species was found to be 3.44 species per $\mathrm{km}^{2}$, and we recorded 0.626 elephants per $\mathrm{km}^{2}$ across the sanctuary. The density of elephants in a habitat fluctuates with changes in ecological characteristics, seasonal variations, and the rate of human interference (Valiex, Fritz, Chamaille-Jammes, Bourgarel, \& Murindagomo, 2008; Sukumar, 1989a; Desi, 1991). The highest elephant density per $\mathrm{km}^{2}$ was 0.126 and the lowest was 0.108 within our study area in an $1800 \mathrm{~km}^{2}$ area in Bangladesh compared to an Indian 110,000 $\mathrm{km}^{2}$ study area with a highest elephant density of 0.299 per $\mathrm{km}^{2}$ and lowest of 0.217 , while in Myanmar the highest density was 0.046 per $\mathrm{km}^{2}$ and lowest density was 0.034 in a $115,000 \mathrm{~km}^{2}$ study area (Santiapillai \& Jackson, 1990; Sukumar, 2003). Sufficient sources of food and water locations for resting and shelter along with access to free-feeding trails, increase the number of elephant visits to different areas (Sukumar, 1989b). Elephants prefer to select feeding trails in forests in relation to the quality and availability of fodder species (Oliver, 1978; Sukumar, 2006). However, immense anthropogenic pressure is always presenting threats to stable and steady ecological factors (Sarker \& Røskaft, 2010; Bari \& Dutta, 2004), such as cattle ranching, gardening, paddy cultivation, vegetable growing, forest resource collection, and roadsides near forests, which all negatively affect forest ecological factors (Baskaran, Balasubramanian, Swaminatahan, \& Deasi, 1995; Sukumar, 1989b; Owen-Smith, 2004). Interference by illegal and legal settlers from the nearest villages to the forest modify the original forest features, absorb waterbodies and damage elephant resting places and movement trails (Chowdhury, 1993; Molla, Rahman, \& Rahman, 2004). Determining fodder species abundances is a central dogma of elephant presence or absence in a habitat (Sarker \& Røskaft, 2011). Our year-round research determined that, at a few sites, the presence of elephants was at satisfactory levels due to an abundance of fodder species but with low impacts from other ecological factors.

\section{Conclusion and Remarks}

Our research location in the TWS, which is a well-known habitat for migratory Asian elephants in the southeastern part of Bangladesh, is located at the border between two countries, Bangladesh and Myanmar. The presence and absence of elephants in this sanctuary are mainly regulated by site qualities over time. The abundance of fodder species, water availability, feeding, and resting facilities with soil types are defined as ecological factors and represent the crucial components of a site. Elephants choose site quality benchmarks that depend on the quality of these ecological factors. The quality risks of these ecological factors have deteriorated and have been impacted by seasonal variations, climate change effects, and anthropogenic interference. Our findings revealed that diversification of fodder species along with other ecological factor qualities were also found to vary across the sites in this sanctuary and were based on the variations in site qualities. The vital ecosystem services in the sanctuary face serious trouble and will eventually decline due to the deterioration in the quality of the five abovementioned ecological factors. It is essential to develop a good plan and 
diversified initiatives for this sanctuary so that the burdens on elephant habitat can be mitigated. The forest authority, local elites, local administration, conservationists, and environmentalists must immediately focus on the importance of this sanctuary to improve its degraded features and characteristics. Effective awareness programs, multidimensional research activities, imposing stringent rules, and regulations for the sanctuary might be the wake-up call in the context of rescuing this precious elephant habitat.

\section{Acknowledgements}

We would like to express our gratitude to our research correspondents and assistants. Finally, our thanks are also expressed to the university authorities, who provided us with the opportunity to perform this research. We would also like to express our gratitude to the local administration and forest department, who provided us with all types of help and support.

\section{References}

Augustine, D. J., \& McNaughton, S. J. (1998). Ungulate effects on the functional species composition of plant communities: herbivore selectivity and plant tolerance. Journal of Wildlife Management, 62, 1165-1183. https://doi.org/10.1111/j.1365-2664.2004. 00864.x

Bari, A., \& Dutta, U. (2004). Co-management of tropical forest resources in Bangladesh. Secondary data collection for pilot protected area: Teknaf Game Reserve. USAID-Bangladesh and Ministry of Environment and Forest, Govt. of People's Republic of Bangladesh. (pp. 01-33).

Barnes, R. F. W. (1983). The elephant problem in Ruaha National Park, Tanzania. Biological Conservation, 26, $127-148$. http://dx.doi.org/10.1016/0006-3207(83)90062-9

Baskaran, N. (1998). Ranging and Resources Utilization by Asian Elephant (Elephas maximus) in the Nilgiri Biosphere Reserve, South India. Ph.D. thesis, Bharathidasan University, Thiruchirapalli.

Baskaran, N., Balasubramanian, M., Swaminatahan, S., \& Deasi, A. A. (1995). Home range of elephants and its implications for the management of Nilgiri Biosphere Reserve, South India. In: A week with elephants (eds. Daniel JC, Datye HS), (pp. 296-313). Bombay Natural History Society, Oxford University Press, Bombay.

Bell, R. H. V. (1982). The effect of soil nutrient availability on community structure in African ecosystems. In: Huntley BJ, Walker BH (eds) Ecology of Tropical Savannahs. Springer, Berlin, (pp. 193-216). https://doi.org/10.1007/978-3-642-68786-0_10

Belovsky, G. E. (1997). Optimal foraging and community structure: The allometry of herbivore food selection and competition. Evolutionary Ecology, 11, 641-672. https://doi.org/10.1023/A:1018430201230

BMD. (2019). Annual meteorological report: Bangladesh Meteorological Department, Agargaon, Dhaka-1207.

Bryant, J. P., Provenza, F. D., Pastor, J., Reichardt, P. B., Claused, T. P., \& Du Toit, J. T. (1991). Interactions between woody plants and browsing mammals mediated by secondary metabolites. Annual Review of Ecology and Systematics, 22, 431-446.

Caughley, G. (1976). The elephant problem an alternative hypothesis. East African Wildlife Journal, 14, $265-283$. https://doi.org/10.1111/j.1365-2028.1976.tb00242.x

Caughley, G., \& Goddard, J. (1975). Abundance and distribution of elephants in Luangwa Valley, Zambia. East African Wildlife Journal, 13, 39-48. https://doi.org/10.1111/j.1365-2028.1975.tb00122.x

Choudhury, A. (1999). Status and conservation of the Asian elephant Elephas maximus in north-eastern India. Mammal Review, 29, 141-171. https://doi.org/10.1046/j.1365-2907.1999.00045.x

Chowdhury, J. H. (1993). Forest Department, Ministry of Environment and forest, Draft Revised Management Plan for Cox's Bazaar Division, 1991-92 to 2000-2001. Volume 1, Working Plans Division, Chittagong, Bangladesh.

Choudhury, M. U. (1969). Working plan of Cox's Bazar Forest division 1968-69 to 1977-78. Forest Department, Government of East Pakistan.

Clegg, B. W., \& O’Connor, T. G. (2012). The vegetation of Malilangwe Wildlife Reserve, south-eastern Zimbabwe. African Journal of Range \& Forage Science, 29, 109-131. https://doi.org/10.2989/10220119.2012.744352

Codron, J., Lee-Thorp, J. A., Sponheimer, M., Codron, D., Grant, R. C., \& De Rutter, D. (2006). Elephant (Loxodonta Africana) diets in Kruger National Park, South Africa: Spatial and Landscape Differences. Journal of Mammalogy, 87(1), 27-34. https://doi.org/10.1644/05-MAMM-0017R1.1

Cumming, D. H. M., Fenton, M. B., Rautenbach, I. L., Taylor, R. D., Cumming, G. S., Cumming, M. S., \& Portfors, C. V. R. (1997). Elephants, woodlands and biodiversity in southern Africa. South African Journal of Science, 93, $231-236$. 
Daniel, J. C. (1980). The status of the Asian elephants in the Indian Sub-continent IUCN/SSC Report. Bombay Natural History Society, Bombay. India.

De Boer, W. F., Ntumi, C. P., Correia, A. U., \& Mafuca, J. M. (2000). Diet and distribution of elephant in the Maputo Elephant Reserve, Mozambique. African Journal of Ecology, 38, 188-201. https://doi.org/10.1046/j.13652028.2000.00243.x

Desai, A. A. (1991). The home range of elephants and its implications for management of the Mudumalai Wildlife Sanctuary, Tamil Nadu. Journal of the Bombay Natural History Society, 88, 145-156. Hornbill House, Bombay publisher, India.

Dhakal, G., \& Ojha, N. (1995). Studies on diet preferences of the elephant (Elephas maximus) in the Royal Chitwan National Park. Tiger paper (FAO), 22(4), 29-31.

DoE. 2012. Bangladesh Environment and Climate Change Outlook. Department of Environment, Ministry of Environment and Forests, Government of Bangladesh, Dhaka. (pp. 138).

Douglas, H. W., \& Sheldrick, D. L. W. (1964). The chemical composition of a day's diet of an elephant. East African Wildlife Journal, 2, 51-60. https://doi.org/10.1111/j.1365-2028.1964.tb00196.x

Douglas-Hamilton, I., Krink, T., \& Vollrath, F. (2005). Movement and corridors of African elephant in relation to protected areas. The Science of Nature, 93(4), 158-163. https://doi.org/10.1007/s00114-004-0606-9

Dublin, H. T. (1996). Elephants of the Masai Mara, Kenya: seasonal habitat selection and group size pattern. Pachyderm, 22, 25-35.

Duncan, P. (1983). Determinants of the use of habitat by horses in Mediterranean wetlands. Journal of Animal Ecology, 52, 93-109. https://doi.org/10.2307/4590

duToit, J. T., Bryant, J. P., \& Frisby, K. (1990). Regrowth and palatability of Acacia shoots following pruning by African savanna browsers. Ecology, 71, 149-154. https://doi.org/10.2307/1940255

Field, C. R. (1971). Elephant ecology in the Queen Elizabeth National Park, Uganda. East African Wildlife Journal, 9, 99-123. https://doi.org/10.1111/j.1365-2028.1971.tb00223.x

Field, C. R., \& Ross, I. C. (1976). The savanna ecology of Kidepo Valley National Park. I. Feeding ecology of Elephant and giraffe. East African Wildlife Journal, 14, 1-15. https://doi.org/10.1111/j.1365-2028.1976.tb00148.x

Fornara, D. A., \& du Toit, J. D. (2007). Browsing lawns? Responses of Acacia nigrescens to ungulate browsing in an African savanna. Ecology, 88, 200-209. https://doi.org/10.1890/0012-9658(2007)88[200: BLROAN]2.0.CO;2

Gadd, M. E. (2002). The impact of elephants on the Marula tree (Sclerocarya birrea). African Journal of Ecology, 40, 328-336. https://doi.org/10.1046/j.1365-2028.2002. 00385.x

Graham, M. D., Douglas-Hamilton, I., Adams, W. M., \& Phyllise, C. L. (2009). The movement of African elephants in a human-dominated land-use mosaic. Animal Conservation, 12(5), 445-455. https://doi.org/10.1111/j.1469-1795.2009. 00272.x

Green, M. J. B. (1987). World Conservation Monitoring Centre IUCN Commission on National Parks and Protected Areas, Teknaf Game Reserve. IUCN Directory of South Asian Protected Areas. (pp. 38-43).

Guy, P. R. (1975). The daily food intake of the African elephant in the Sengwa area, Rhodesia. Arnoldia (Rhodesia), 7 , $1-8$.

Guy, P. R. (1976a). The feeding behaviour of elephants in Sengwa area. Rhodesia. Arnoldia (Rhodesia), 6, 55-63. https://hdl.handle.net/10520/AJA03794369_3337

Guy, P. R. (1976b). Diurnal activity patterns of the elephant in the Sengwa Area. Rhodesia. East African Wildlife Journal, 14, 285-295. https://doi.org/10.1111/j.1365-2028.1976.tb00243.x

Hassan, M. M. (2017). Monitoring land use/land cover change, urban growth dynamics and landscape pattern analysis in five fastest urbanized cities in Bangladesh. Remote Sensing: Applications: Society and Environment, 7, 69-83. https://doi.org/10.1016/j.rsase.2017.07.001

Hedges, S., Tyson, M. J., Sitompul, A. F., Gunaryadi, D., \& Aslan, A. (2005). Distribution, status and conservation needs of Asian elephants (Elephus maximus) in Lampung province, Sumatra, Indonesia. Biological Conservation, 124, 35-48. https://doi.org/10.1016/j.biocon.2005.01.004

Himmelsbach, W., Tagle, M. A. G., Fuldner, K., Hoefle, H. H., \& Htun, W. (2006). Food plants of Captive elephants in the Okkan Reserve Forest, Myanmar, Southeast Asia. ECOTROPICA, 12, 15-26. 
Ishwaran, N. (1983). Elephant and woody-plant relationships in Galoya, Sri Lanka. Biological Conservation, 26 (3), $255-$ 70. https://doi.org/10.1016/0006-3207(83)90077-0

Islam, S. A., Miah, M. A. Q., \& Habib, M. A. (2013). Diversity of fruit and timber tree species in the coastal homesteads of southern Bangladesh. Journal of the Asiatic Society of Bangladesh, Science., 39(1), 83-94. https://doi.org/10.3329/jasbs.v39i1.16037

IUCN Bangladesh. (2015). Red List of Bangladesh: A brief on assessment result 2015. IUCN, International Union for Conservation of Nature, Bangladesh Country Office, (Dhaka. pp. 24).

Jachmann, H. (1983). The ecology of the Kasungu elephant. Ph.D. thesis, University of Groningen.

Jachmann, H. (1989). Food selection by elephants in the "Miombo" home in relation to leaf chemistry. Biochemical Systematic Ecology, 17, 15-24. https://doi.org/10.1016/0305-1978(89)90037-9

Jachmann, H., \& Bell, R. H. V. (1985). Utilization by elephants of the Brachystegia woodlands of the Kasungu National Park, Malawi. African Journal of Ecology, 23, 245-258. https://doi.org/10.1111/j.1365-2028.1985.tb00955.x

Jachmann, H., \& Croes, T. (1991). Effects of browsing by elephants on the Combretum/Terminalia woodlands at the Nazinga Game Ranch, Burkina Faso, West Africa. Biological Conservation, 57, 13-24.

Jackson, R. B., Manwaring, J. H., \& Caldwell, N. M. (1990). Rapid physiological adjustment of roots to localized soil enrichment. Nature, 344, 58-60. https://doi.org/10.1038/344058a0

Karunaratne, S. H. P. P., \& Ranawana, K. A. (1999). A preliminary study on feeding activity patterns and budgets of domesticated elephants (Elephas maximus maximus) in Sri Lanka. Ceylon Journal of Science, Biological Science, 27(1), 61-65.

Khan, M. M. H. (2008). Protected Areas of Bangladesh- a guide to wildlife. Nishorgo Program, Bangladesh Forest Department, Dhaka. (pp. 304).

Laws, R. M. (1970b). Elephants as agents of habitat and landscape change in East Africa. Oikos, 21, 1-15. https://doi.org/10.2307/3543832

Laws, R. M., Parker, I. S. C., \& Johnstone, R. C. B. (1975). Elephants and Their Habitats. The Ecology of Elephants in North Bunyoro, Uganda. Clarendon Press, Oxford.

Lewis, D. M. (1986). Disturbance effects on elephant feeding: evidence for compression in Luangwa Valley, Zambia. African Journal of Ecology, 24, 227-241. https://doi.org/10.1111/j.1365-2028. 1986.tb00367.x

Mallegowda, P., Rengaian, G., Krishnan, J., \& Niphadkar, M. (2015). Assessing Habitat Quality of Forest-Corridors through NDVI Analysis in Dry Tropical Forest of South India: Implications for Conservation. Remote Sensing, 7, 1619-1639. https://doi.org/10.3390/rs70201619

Malpas, R. C. (1978). The ecology of the African elephant in the Rwenzori and Kabalega Falls National Park, Uganda. Ph.D. thesis, University of Cambridge.

Mannan, M. A. (2006). Plant Biodiversity Management at Teknaf Peninsula ECA. Coastal \& Wetland Biodiversity Management Project, Cox's Bazar Site Office. 4, 7-8.

McKay, G. M. (1973). Behaviour and ecology of the Asiatic elephant in southeastern Ceylon. Smithson Institution Press, Washington. https://doi.org/10.5479/si.00810282.125

McNaughton, S. J. (1985). Ecology of a grazing ecosystem: the Serengeti. Ecological Monographs, 55, 259-294. https://doi.org/10.2307/1942578

Molla, A. R., Rahman, M. M., \& Rahman, M. S. (2004). Site-level field appraisal for protected area co-management: Teknaf game reserve. Nature Conservation Movement (NACOM), Bangladesh. Prain, D. 1903. Bengal Plants. Vols. 1 $\&$ 2. (Ind. Repr. 1963). Botanical Survey of India, Calcutta.

Mukul, S. A. (2007). Biodiversity conservation strategies in Bangladesh: the state of protected areas. Tiger paper, 34(3), $28-32$.

Nishat, A., Huq, S. M. I., Barua, S. P., Khan, A. H. M., \& Moniruzzaman, A. S. (eds) (2002). Bioecological Zones of Bangaldesh. IUCN, Bangladesh Country Office, Bangladesh, Dhaka. (pp. 141).

Oliver, R. C. D. (1978). On the ecology of Asian elephant. Ph.D. thesis, Cambridge University. Cambridge, Cambridge, UK.

Osborn, F. V. (1998). The ecology of crop-raiding elephants in Zimbabwe. PhD thesis, University of Cambridge, Cambridge, UK. 
Osborn, F. V. (2004). Seasonal variation of feeding patterns and food selection by crop raiding elephants in Zimbabwe. African Journal of Ecology, 42, 322-327. https://doi.org/10.1111/j.1365-2028.2004. 00531.x

Owen-Smith, R. N. (1988). Mega herbivores: The influence of very large body size on ecology. Cambridge University press, Cambridge. https://doi.org/10.1017/CBO9780511565441

Owen-Smith, N., \& Chafota, J. (2012). Selective feeding by a megaherbivore, the African elephant (Loxodonta africana). Journal of Mammal, 93, 698-705. https://doi.org10.2307/23259965

Pellew, R. A. (1984). The feeding ecology of a selective browser, the giraffe. Journal of Zoology, 202, 57-81. https://doi.org/10.1111/j.1469-7998.1984.tb04288.x

Pradhan, N. M. B., Wegge, P., \& Moe, S. R. (2007). How does a re-colonizing population of Asian elephants affect the forest habitat? Journal of Zoology, 273, 183-191. https://doi.org/10.1111/j.1469-7998.2007. 00313.x

Pringle, R. M. (2008). Elephants as agents of habitat creation for small vertebrate at the patch scale. Ecology, 89, 26-33. https://doi.org/10.1890/07-0776.1

Rahman, M. Z. (2018). Livelihoods of Rohingyas and Their Impacts on Deforestation. In Deforestation in the Teknaf Peninsula of Bangladesh; Springer: Singapore. https://doi.org/10.1007/978-981-10-5475-4_9

Rosario, E. A. (1997). The conservation management plan of the protected areas other than those in Sundarbans Forest in Bangladesh. GOB/WB forest resource management project in Bangladesh.

Roy, M. (2009). Habitat use and foraging ecology of the Asian Elephant (Elephas maximus) in Buxa Tiger Reserve and adjoining areas of northern West Bengal. Ph.D. thesis, Department of Zoology, Vidyasagar University, Paschim Medinipur, West Bengal, India.

Santiapillai, C., \& Jackson, P. (1990). The Asian elephants: An Action Plan for its conservation. IUCN, Gland, Switzerland.

Sarker, A. H. M. R., \& Røskaft, E. (2010). Human attitudes towards conservation of Asian elephants (Elephas maximus) in Bangladesh. International Journal of Biodiversity and Conservation, 2(10), 316-327. http://www.academicjournals.org/ijbc

Sarker, A. H. M. R., \& Røskaft, E. (2011). Human attitudes towards the conservation of protected areas: a cause study from four protected areas in Bangladesh. Oryx, 45(3), 391-400. https://doi.org/10.1017/S0030605310001067

Sarker, A. H. M. R., \& Røskaft, E. (2014). Perceptions of Farmers in Bangladesh to Asian Elephants (Elephas maximus). Environment and Natural Resources Research, 4(2), 23-38. https://doi.org/10.5539/enrr.v4n2p23

Sarker, A. H. M. R., Hossen, A., \& Røskaft, E. (2015). Fatal Elephant Encounters on Humans in Bangladesh: Context and Incidences. Environment and Natural Resources Research, 5(2), 81-90. https://doi.org/10.5539/enrr.v5n2p99

Sharma, U. R., \& Yonzon, P. B. (eds.) (2005). People and Protected Areas in South Asia. IUCN World Commission on Protected areas (South Asia Office) and Resources Himalaya Foundation: Kathmandu.

Stokke, S. (1999). Sex differences in feeding-patch choice in a megaherbivore: elephants in Chobe National Park, Botswana. Canadian Journal of Zoology, 77, 1723-1732. https://doi.org/10.1139/z99-145

Stokke, S., \& duToit, J. T. (2000). Sex and size related differences in the dry season feeding patterns of elephants in Chobe National Park, Botswana. Ecography, 23, 70-80. https://doi.org/10.1111/j.1600-0587.2000.tb00262.x

Sukumar, R. (1989a). Ecology of Asian elephant in Southern India I. Movement and habitat utilization pattern. Journal of Tropical Ecology, 5, 1-18. https://www.jstor.org/stable/2559605

Sukumar, R. (1989b). The Asian elephants' ecology and management. Cambridge University press, Great Briton, (pp. 251).

Sukumar, R. (1990). Ecology of Asian elephant in South India II. Feeding habits and crop raiding pattern utilization patterns. Journal of Tropical Ecology, 6, 33-53. https://www.jstor.org/stable/2559367

Sukumar, R. (2003). The living elephants-evolutionary, ecology, behaviour and conservation. Oxford University Press, Oxford.

Sukumar, R. (2006). A brief review of the status, distribution, and biology of wild Asian elephant. International zoo yearbook, 40, 1-8. https://doi.org/10.1111/j.1748-1090.2006. 00001.x

Sukumar, R., Bhattacharya, S. K., \& Krishnamurthy. R. V. (1987). Carbon isotopic evidence for different feeding patterns in an Asian elephant population. Current Science, 56(1), 11-14. https://www.jstor.org/stable/24215793

Uddin, M. Z., Alam, M. F., \& Hassan, M. A. (2012). Diversity in angiosperm flora of Teknaf Wildlife Sanctuary, 
Bangladesh. https://doi.org/10.3329/bjpt.v20i2.17389

USAID. (2015). Land use change trend analysis in seven protected areas in Bangladesh under IPAC through application of Landsat imageries. USAID. Bangladesh.

Vacuylenberg, R. W. B. (1977). Nutritional ecology of the ruminant. Feeding behaviour of the Asiatic elephant in South-east Sri-Lankan in relation to conservation. Biological Conservation, 12, 33-54. https://doi.org/10.1016/0006-3207(77)90056-8

Valiex, M., Fritz, H., Chamaille-Jammes, S., Bourgarel, M., \& Murindagomo, F. (2008). Fluctuations in abundance of large herbivore populations: insights into the influence of dry season rainfall and elephant numbers from long-term data. Animal Conservation, 11, 391-400. https://doi.org/10.1111/j.1469-1795.2008.00194.x

Viljoen, P. J. (1989a). Spatial distribution and movements of elephants (Loxodonta africana) in northern Namib desert region of the Kaokoveld, South West Africa/Namibia. Journal of Zoology, 219, 1-19. https://doi.org/10.1111/j.1469-7998.1989.tb02561.x

Viljoen, P. J. (1989b). Habitat selection and preferred food plants of a desert-dwelling elephant population in the northern Namib Desert, South West Africa/Namibia. African Journal of Ecology, 27, 227-240. https://doi.org/10.1111/j.1365-2028. 1989.tb01016.x

Williams, A. C. (2003). Elephants, their habits in Rajaji Corbett National Parks. Ph.D. thesis, Rajkot, Saurashtra University, India.

Willamson, B. R. (1975). The conditional and nutritional of elephants in Wankie National Park. Arnoldia (Rhodesia), 7, $1-20$.

Wittemyer, G., Getz, W. M., Vollrath, F., \& Douglas-Hamilton, I. (2007). Social dominance, seasonal movements, and spatial segregation in African elephants: a contribution to conservation behavior. Behaviour Ecology and Sociobiology, 61, 1919-1931. https://doi.org/10.1007/s00265-007-0432-0

Yadv, B. R., Dutta, I. C., Chalise, M. K., Williums, C., \& Sharma, B. K. (2013). Habitat utilization by Asian wild elephant (Elephas maximus) in Parsa Wildlife Reserve, Nepal. ECOPRINT, 20, 41-52.

https://doi.org/10.3126/eco.v20i0.11440

\section{Copyrights}

Copyright for this article is retained by the author(s), with first publication rights granted to the journal.

This is an open-access article distributed under the terms and conditions of the Creative Commons Attribution license (http://creativecommons.org/licenses/by/4.0/). 